\title{
Evaluation methods of heavy metal pollution in soils based on enzyme activities: A review
}

\author{
Yongxing Cui ${ }^{1,2}$, Xia Wang $^{1,2}$, Xiangxiang Wang $^{3}$, Xingchang Zhang ${ }^{1}$, Linchuan Fang ${ }^{1,4, *}$ \\ 1 State Key Laboratory of Soil Erosion and Dryland Farming on the Loess Plateau, Institute of Soil and Water Conservation CAS and MWR, \\ Yangling 712100, China \\ 2 University of Chinese Academy of Sciences, Beijing 100049, China \\ 3 College of Natural Resources and Environment, Northwest A\&F University, Yangling 712100, China \\ 4 CAS Center for Excellence in Quaternary Science and Global Change, Xi'an 710061, China
}

H I G H L I G H T S

- Five methods of soil HM pollution evaluation based on enzyme activity were reviewed.

- This review examined the performance and ecological implications of these methods.

- Enzymatic stoichiometry methods reflect changes in soil functions under HM stress.

- Microbial metabolic limitation is a promising indicator to assess soil HM pollution.

\section{ARTICLE INFO}

Article history:

Received December 17, 2020

Revised March 15, 2021

Accepted April 21, 2021

Keywords:

Soil heavy metals

Pollution assessment

Microbial metabolism

Enzyme activities

Ecoenzymatic stoichiometry

Biological indicators

\section{GRAPHICAL ABSTRACT}

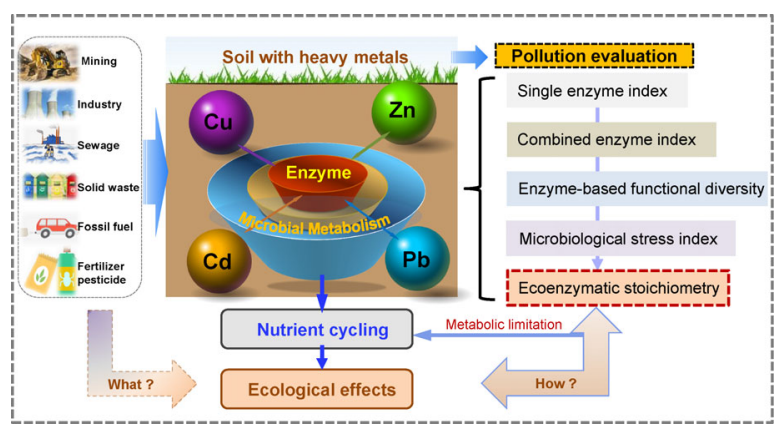

\section{A B S T R A C T}

Soil enzyme activities have been suggested as suitable indicators for the evaluation of metal contamination because they are susceptible to microbial changes caused by heavy metal stress and are strictly related to soil nutrient cycles. However, there is a growing lack of recognition and summary of the historic advancements that use soil enzymology as the proposal of evaluation methods. Here, we review the most common methods of heavy metal pollution evaluation based on enzyme activities, which include single enzyme index, combined enzyme index, enzyme-based functional diversity index, microbiological stress index, and ecoenzymatic stoichiometry models. This review critically examines the advantages and disadvantages of these methods based on their execution complexity, performance, and ecological implications and gets a glimpse of avenues to come to improved future evaluation systems. Indices based on a single enzyme are variable and have no consistent response to soil heavy metals, and the following three composite indices are characterized by the loss of many critical microbial processes, which thus not conducive to reflect the effects of heavy metals on soil ecosystems. Considering the dexterity of ecoenzymatic stoichiometry methods in reflecting changes in soil functions under heavy metal stress, we propose that microbial metabolic limitations quantified by ecoenzymatic stoichiometry models could be promising indicators for enhancing the reality and acceptance of results and further improving the potential for actual utility in environmental decision-making.

๑) Higher Education Press 2021

\section{Introduction}

* Corresponding author

E-mail address: flinc629@hotmail.com (L. Fang)
Heavy metal pollution has become a critical issue within many soil ecosystems (Facchinelli et al., 2001; Schloter et al., 
2017). Even though heavy metals exist naturally in soil, anthropogenic activities, such as industrialization, agriculture, mining, and urbanization, are the most significant source (Bhuiyan et al., 2010; Li et al., 2014; Ali et al., 2017). Heavy metal pollution leads to a deterioration in soil quality and a loss of soil functions (Schloter et al., 2017; Wang et al., 2017a), which is harmful to human health, mainly through soil-plant systems and soil-crop-food chains (Wood et al., 2016; Shen et al., 2017). Remediation of heavy metal contaminated soil has thus become an important and extensively studied topic (Zota et al., 2009; Violante et al., 2010; Ju et al., 2019). At the same time, the persistent threat of heavy metal contamination in soil ecosystems has prioritized the development of strict directives for soil protection and pollution assessments, which the European Union (EU) has recently promoted (Schloter et al., 2017). Accordingly, the importance of developing reliable, robust, and resilient indicators to monitor soil heavy metal contamination has been emphasized to establish early warning and assessment systems.

Soil enzymes are prerequisites of organic matter decomposition and nutrient cycling, representing microbial metabolism and their response to environmental change (Burns et al., 2013). Thus, many enzymes are viewed as powerful biological indicators for evaluating heavy metal toxicity and soil health (Xian et al., 2015; Wang et al., 2019). Moreover, the assessment of the microbial metabolic activities can precede some detectable changes such as soil chemo-physical properties, which strongly support the utility of using enzymatic activity as an early warning tool for monitoring soil pollution with heavy metals (Wahsha et al., 2017; Schloter et al., 2017). In particular, among all kinds of evaluation methods based on enzyme activities, ecoenzymatic stoichiometry is an emerging methodology that incorporates multiple enzyme activities into specific microbial metabolic characteristics (Moorhead et al., 2016; Cui et al., 2018), reflecting the intensity of microbial metabolism as well as the ability of microorganisms to obtain energy and nutrients (Sinsabaugh et al., 2009). This new methodology has been used to assess elemental cycles and energy flow within ecological systems (Tapia-Torres et al., 2015) and to identify microbial response to environmental change (Cui et al., 2018; Cui et al., 2019a) and heavy metal contaminate (Wang et al., 2020). However, with the development of new methods, there is urgency to compare and review those representative methods for facilitating future research and improving their practical application.

In this review, we address how methodological developments in the last decades have revolutionized our ability to evaluate soil heavy metal contamination, and how this knowledge can be used to develop improved indicators of soil pollution based on enzyme activities. Finally, because of extracellular enzyme activity representing a characterization of microbial metabolic response to environmental stress and the practicability of evaluating indicators, we would recommend the emerging enzyme stoichiometry models as a promising methodology in evaluating soil heavy metal pollution.

\section{Development of enzyme-related indicators}

\subsection{Single enzyme index}

Extracellular enzymes produced by microorganisms are susceptible to soil environmental changes, and they are crucial participants in soil nutrient cycles and functional sustainability (Sinsabaugh et al., 2009; Duan et al., 2018; Cui et al., 2018). Over the past two decades, extracellular enzymes have increasingly been used to evaluate soil heavy metal pollution (Hagmann et al., 2015; Fang et al., 2017; Wang et al., 2020). Long et al. (2009) reported that alkaline or acid phosphatase $(\mathrm{PHO})$, which plays an essential role in the decomposition of organic $P$ compounds, can be used as bioindicators of heavy metal pollution. Liang et al. (2014) and Xian et al. (2015) both found that catalase can decompose $\mathrm{H}_{2} \mathrm{O}_{2}$ and protect organisms against damage, and thus has been widely used as a bio-indicator to detect the presence of a variety of heavy metal pollutants. Hu et al. (2014) proposed using dehydrogenase $(\mathrm{DH})$ as a catalyst for substrate dehydrogenation, suggesting that this enzyme can also be used as an indicator for evaluating heavy metal contamination. However, we summarized 12 kinds of enzymes reported in previous studies with inconsistent activity responses to heavy metals (Table 1). This indicated that enzymatic activities are highly variable in their response to heavy metals in soil, which could depend on differences in enzyme functions, soil properties, heavy metal species, and concentrations (Kandeler et al., 2000; Yang et al., 2016; Wahsha et al., 2017). The inconsistencies in responses imply incomparability of enzyme indicators in evaluating heavy metal pollution (Schloter et al., 2017; Duan et al., 2018). As a result, integrating diverse enzymes widely representative of microbial metabolism into a comprehensive indicator could be both necessary and promising for assessing heavy metal toxicity levels in soil microbes and identifying the ecological effects of heavy metal pollution in soil systems.

\subsection{Combined enzyme index}

Many efforts have been made to condense the achieved information of enzyme activities in a numerical value, an index capable of differentiating between soils with different quality features or affected by heavy metal pollution (Rao et al., 2014). For example, arylsulphatase (ARYL), urease (UR), and $\mathrm{PHO}$ are involved in sulfur $(\mathrm{S})$, nitrogen $(\mathrm{N})$, and phosphorus (P) cycles, respectively. $\mathrm{DH}$ represents a measure of viable microorganisms and their oxidative capability (Trevors, 1984). Invertase (INV), $\beta$-glucosidase (GLU) and o-diphenol oxidase (DPO) are three enzymes involving in the carbon (C) cycle, and fluorescein diacetate hydrolase (FDAH) has also been often used as a sensor and functional indicator of soil health (Adam and Duncan, 2001). All of them have been tried as indicators for the evaluation of heavy metal pollution. However, the choice of which enzyme activities should be involved in the index is not straightforward. Nanniperi el al. 


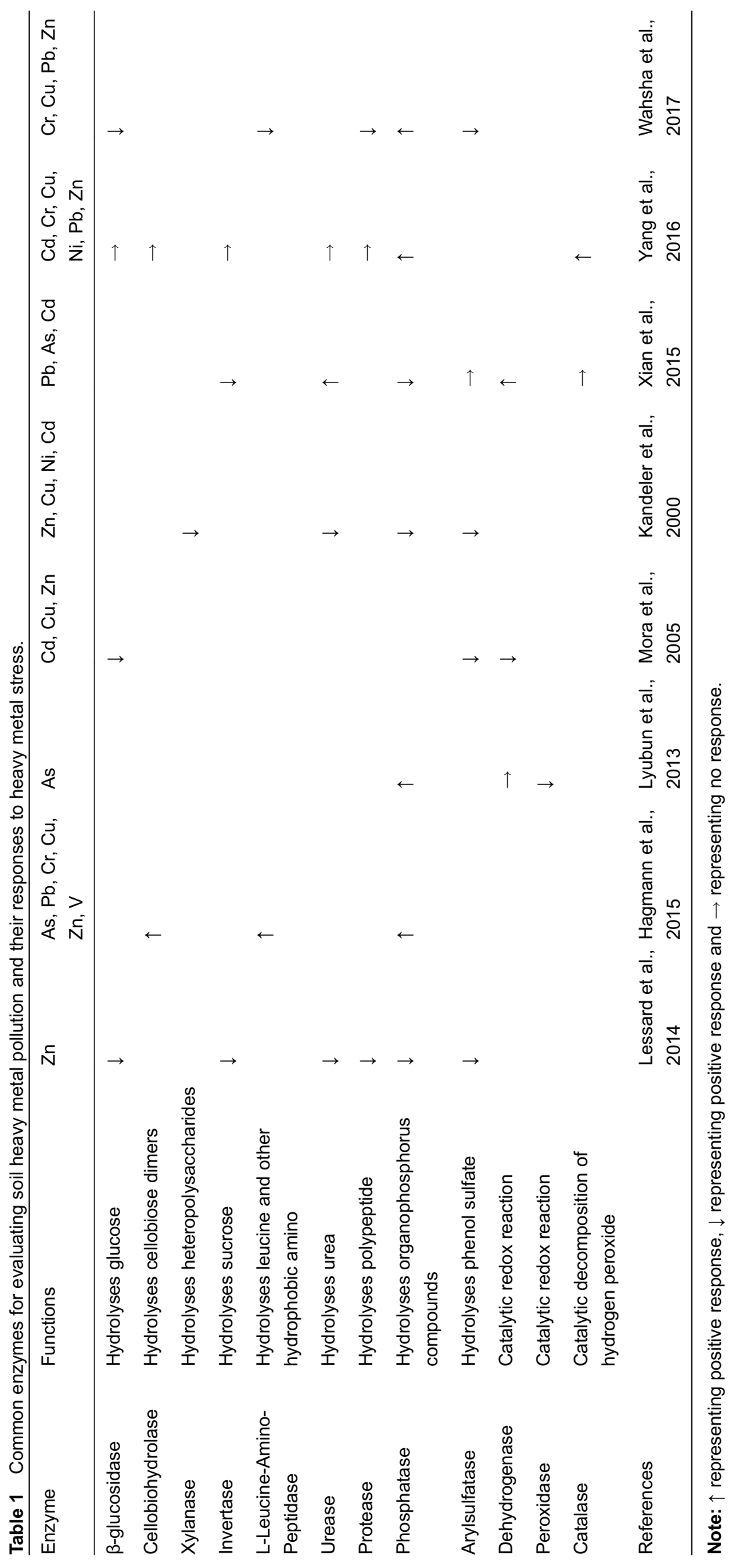


(2002) stated that chosen enzyme activities should be those involved in a key or particular processes such as organic matter degradation, $\mathrm{N}$ mineralization, or nitrification. At present, just some indices were applied to a limited number of soils.

Puglisi et al. (2006) developed a numerical index based on seven enzyme activities (ARYL, GLU, PHO, UR, INV, DH, DPO). The enzyme activities were measured in three soils characterized by contamination by repeated overflowing with municipal and industrial wastes, intensive cultivation without either crop rotation or organic fertilization, and irrigation with brackish water (Gianfreda et al., 2005). At each site, neighboring soils, having similar properties but not subjected to degradation or to poor agricultural practices, were used as control soils. Finally, two indices $\mathrm{Al} 1$ and $\mathrm{Al} 2$ were developed utilizing canonical discriminant analysis for evaluating soil heavy metal pollution, one comprising all seven measured enzymatic activities and another with the most common enzymatic activities studied in the literature, i.e., GLU, PHO and UR.

$$
\begin{aligned}
\text { AI } 1= & -21.30 \text { ARYL } \\
& +35.2 \text { GLU }-10.20 \text { PHO }-0.52 \mathrm{UR}-4.53 \mathrm{INV} \\
& +14.3 \mathrm{DH}+0.003 \mathrm{DPP} ;
\end{aligned}
$$

AI $2=7.87$ GLU -8.22 PHO-0.49 UR.

However, these empirical indices with fixed coefficients may not apply to evaluating heavy metal pollution in other environments. We also note that this principal component analysis-based approach impedes their practical utility as ecological indicators such as reflecting microbial metabolic changes. As a result, the development of soil enzyme index usable as a reliable measure of soil health and functions after contaminated by heavy metals is still a key research priority that requires new approaches, ideas and technologies.

\subsection{Enzyme-based functional diversity index}

Recent studies further aggregated and integrated the responses of various soil enzymatic activities to heavy metals and proposed microbial functional diversity (FD) indices based on soil enzymes (Lessard et al., 2014). The FD indices are summarized in Table 2. These enzyme-based aggregated FD indices provide many advantages because these enzymes integrated into indices cover most biogeochemical cycles and may be measured easily and relatively economically (German et al., 2011; Burns et al., 2013; Lessard et al., 2014; Hagmann et al., 2015). As a result, various enzymatic FD indices were developed and used in past studies. One of the most prevalent categories is associated with the aggregation of the classic enzymatic responses by the FD indices conventionally used in structural diversity. For example, the Shannon index was mainly used (Epelde et al., 2008; Marinari et al., 2012), and the Simpson and Gini indices were also reported (Pignataro et al., 2012) as the evaluation indices of heavy metal pollution. Other studies also used multiple linear regressions, including many enzymes as independent variables, to build the comprehensive indices (Puglisi et al., 2006; Bastida et al., 2008).

The aggregated soil enzymatic response was calculated using a weighted and geometric mean and the conventional FD indices, which have been listed in Table 2 . Since the units of soil enzyme activities vary widely, the activities of each enzyme are normalized before being summed up by dividing the individual enzyme activities of each contaminated soil by the individual enzyme activities of its paired reference soil (Lessard et al., 2014). The aggregated FD indices are equivalent in terms of reducing the various enzymatic variables into one. A principal component analysis (PCA) was carried out in parallel to validate whether the total variance of the data set is mainly explained by a single principal component. However, the main issue of this approach is the lack of flexibility of the proposed equation. In addition, dimensionality reduction analysis to values of enzyme activity of different functions loses much valuable information such as characterization of specific nutrient cycles.

\subsection{Microbiological stress index}

It is well known that microorganisms play determinant roles in maintaining the sustainability of soil ecosystem function and services (Bahram et al., 2018). Assessment of combined effects of heavy metals at the ecosystem function level could help address the ecological significance of toxic effectsand improve the ecological risk assessment (ERA) framework for heavy metal pollution in soils. The integrated functional sensitivity and stability of soil microbial communities, may gauge changes in ecological functions, characterize the stressed soil ecosystems and contribute essentially to maintaining soil ecosystem function and services when additional environmental disturbances arise (Griffiths and Philippot, 2013). Therefore, these two attributes appear to be exceptionally reasonable and applicable assessment endpoints in evaluating the realistic toxic effect of contaminants on the functioning process of soil ecosystem (US Environmental Protection Agency, 2016; Jiang et al., 2019). The terms of soil resistance (the inherent capacity of soil to withstand stress/disturbance) and resilience (the ability of soil to recover after stress/disturbance) were introduced to quantify the stability of soil microbial communities subjected to different types of stress/disturbance (Griffiths et al., 2001).

Consequently, the stress index (SI) is used to quantify the sensitivity of soil microbial communities to stress such as heavy metal contamination (Wang et al., 2017b). Dagnino et al. (2008) proposed that the SI can be evaluated by comparing the relative stress response $(R S R)$ with the critical threshold values. Specifically, the integrated functional sensitivity (MSI), resistance (MRS) and resilience (MRL) of soil microbial communities were also proposed and formulized, which can be seen in Wang et al. (2017b) and Jiang et al. 


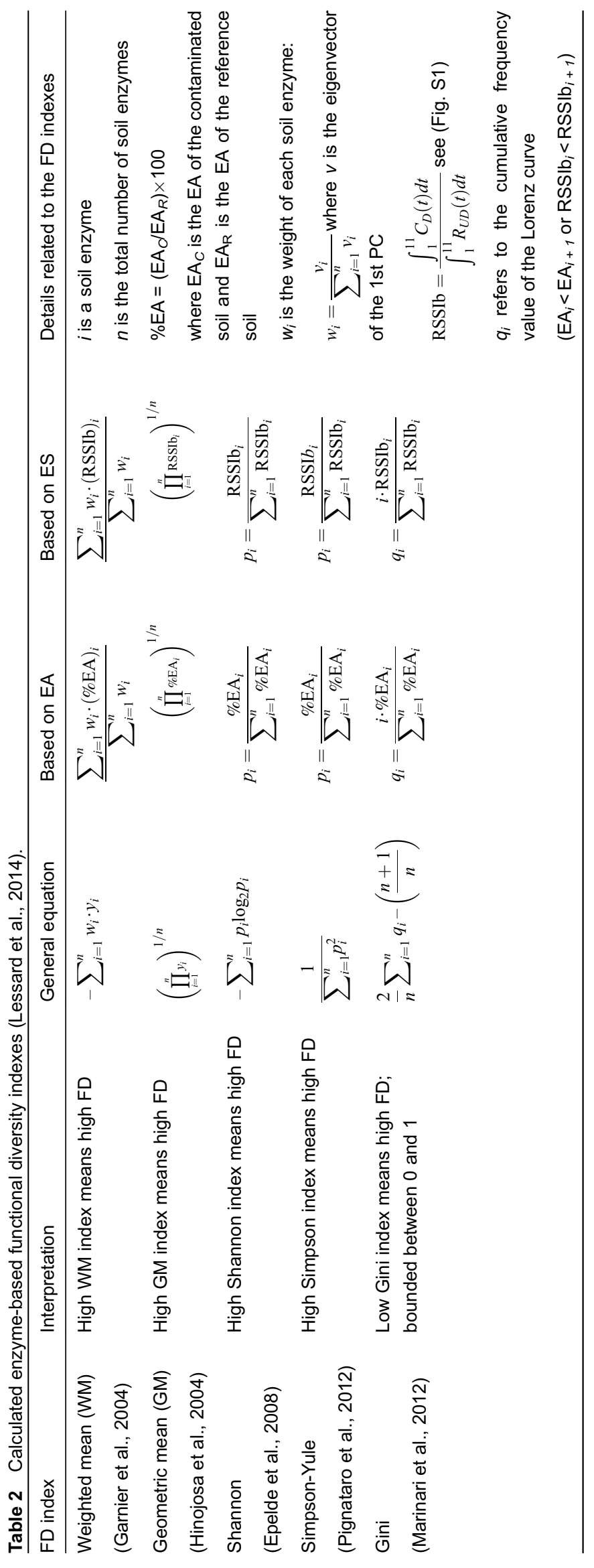


(2019). However, these protocols require microbial extraction and cultivation, representing only a tiny part of microbial metabolisms, and other biogeochemical cycles such as S, P and $\mathrm{N}$ cycles are not taken into account. These two factors constitute important limits that impede the methods of widespread use (Lessard et al., 2014; Jiang et al., 2019).

\subsection{Ecoenzymatic stoichiometry models}

Heavy metal contaminants could be a significant threat to soil functions (e.g., C cycling) due to their chronicity and universality in soil (Wang et al., 2020). Therefore, it is also essential to establish robust indicators that report on the changes of microbial metabolisms and thus soil functions. Ecoenzymatic stoichiometry is an emerging methodology that incorporates multiple parameters associated with enzyme activities into specific indices (Sinsabaugh et al., 2009; Moorhead et al., 2016), which reflects the microbial metabolic limitations as well as soil nutrient status. Corresponding ecoenzymatic stoichiometry models typically incorporate multiple enzyme activities in the soil $\mathrm{C}, \mathrm{N}$, and $\mathrm{P}$ cycles (Table S1). As a result, this new methodology has been used to assess soil nutrient cycles and microbial metabolic functions within ecological systems (Tapia-Torres et al., 2015; Cui et al., 2019b) and to identify microbial response to environmental change (Cui et al., 2018, 2019a). Up to now, five common ecoenzymatic stoichiometry models were proposed (Table 3 ), which are robust and concise means to characterize the metabolic characteristics of microorganisms in responding to various environmental changes.

Recently, we have also carried out a series of studies on ecoenzymatic stoichiometry in association with contaminated environments, particularly in heavy metal contaminated soils (Wang et al., 2020). We used extracellular enzyme stoichiometry models to identify the response of microbial metabolism to various heavy metal contaminants and the revealing potential implication of heavy metal contaminants in soil ecosystems. Studies found that microbial metabolism was restricted by soil $\mathrm{C}$ and $\mathrm{P}$ within a heavy metal polluted area in North-west China. Heavy metal stress significantly increased microbial $C$ limitation while decreasing microbial $P$ limitation. However, microbial $\mathrm{C}$ and $\mathrm{P}$ limitations both responded consistently to different heavy metals (i.e., $\mathrm{Cd}, \mathrm{Pb}, \mathrm{Zn}$, and $\mathrm{Cu}$ ). Heavy metals had the most significant effect on microbial C limitation compared to other soil properties, and soil with the lowest heavy metal concentration exhibited the lowest microbial C limitation (Unpublished data). These results indicated that microbial metabolic limitation could robustly and sensitively reflect the degree of heavy metal pollution in soil. Additionally, increased microbial $C$ limitation caused by heavy metals could potentially escalate soil $C$ release by promoting organic matter decomposition and increasing investments in enzyme production and the maintenance of metabolic processes (Fig. 1).

Xu et al. (2018) also reported a reduction in microbial $C$ use efficiency (CUE) in heavy metal contaminated soil. Specifically, microbial CUE values were $0.35,0.29$, and 0.31 in $\mathrm{Cd}$, $\mathrm{Pb}$, and $\mathrm{Cd}+\mathrm{Pb}$ spiked soil, respectively, while it was 0.41 in uncontaminated soil (Xu et al., 2018). Consequently, potential $C$ loss induced by heavy metal pollution on soil ecosystems may be extensive and significant. These results suggest the usefulness of extracellular enzyme stoichiometry as a new method for evaluating the ecological effects of heavy metal pollution, while microbial metabolic limitation could be a promising indicator (Fig. 1). Additionally, the metabolic limitation of soil microorganisms is both typical and highly variable in diversified ecosystems (Sinsabaugh et al., 2009; Moorhead et al., 2016; Cui et al., 2018), which indicated that microbial metabolic limitation is also highly sensitive to environmental change. However, many ecoenzymatic stoichiometry models contain empirical parameters or assumptions, which may significantly reduce the accuracy of predicting the responses of microbial metabolism to heavy

Table 3 The main models of ecoenzymatic stoichiometry for identifying the microbial metabolic limitation or resource allocation.

\begin{tabular}{|c|c|c|c|}
\hline Names & Methods or functions & Performance & Sources \\
\hline Ratio model & $\begin{array}{l}\log _{e}(C): \log _{e}(N), \log _{e}(C): \log _{e}(P) \\
\text { and } \log _{e}(N): \log _{e}(P)\end{array}$ & $\begin{array}{l}\text { Microbial relative } \mathrm{C} \text { limitation, } \mathrm{N} \\
\text { or } \mathrm{P} \text { limitation }\end{array}$ & Sinsabaugh et al., 2008 \\
\hline TER model & $\begin{array}{l}\operatorname{TER}_{\mathrm{C}: \mathrm{N}}=\left(\mathrm{EEA}_{\mathrm{C}: \mathrm{N}} \times \mathrm{B}_{\mathrm{C}: \mathrm{N}}\right) / n_{o} \\
\operatorname{TER}_{\mathrm{C}: \mathrm{P}}=\left(\mathrm{EEA}_{\mathrm{C}: \mathrm{P}} \times \mathrm{B}_{\mathrm{C}: \mathrm{P}}\right) / p_{o}\end{array}$ & Microbial $\mathrm{N}$ and/or $\mathrm{P}$ limitation & Sinsabaugh et al., 2009 \\
\hline Vector analysis model & $\begin{array}{l}\text { Length }=\operatorname{SQRT}\left(x^{2}+y^{2}\right) \\
\text { Angle }\left({ }^{\circ}\right)=\text { DEGREES }(\operatorname{ATAN} 2(x, y))\end{array}$ & $\begin{array}{l}\text { Relative } \mathrm{C} \text { limitation, } \mathrm{N} \text { or } \mathrm{P} \\
\text { limitation }\end{array}$ & Moorhead et al., 2016 \\
\hline Resource allocation models & $\begin{array}{l}\text { CUE }=\mathrm{CUE}^{\max } \times\left[\mathrm{S}_{\mathrm{C}: \mathrm{N}} /\left(\mathrm{K}_{\mathrm{C}: \mathrm{N}}+\mathrm{S}_{\mathrm{C}: \mathrm{N}}\right)\right] \\
=\mathrm{A}_{\mathrm{N}} \times \mathrm{B}_{\mathrm{C}: \mathrm{N}} / \mathrm{TER}_{\mathrm{C}: \mathrm{N}} ; \\
\mathrm{NUE}=\mathrm{NUE}^{\max } \times\left[\mathrm{S}_{\mathrm{N}: \mathrm{C}} /\left(\mathrm{K}_{\mathrm{C}}+\mathrm{S}_{\mathrm{N}: \mathrm{C}}\right)\right] \\
\mathrm{PUE}=\mathrm{PUE}^{\max } \times\left[\mathrm{S}_{\mathrm{P}: \mathrm{C}} /\left(\mathrm{K}_{\mathrm{C}}+\mathrm{S}_{\mathrm{P}: \mathrm{C}}\right)\right]\end{array}$ & Microbial CUE, NUE and PUE & $\begin{array}{l}\text { Sinsabaugh and Follstad Shah, } \\
2012\end{array}$ \\
\hline Ecosystem C dynamic models & $\begin{array}{l}\mathrm{CUE}_{a} \times \mathrm{CUE}_{h}=\mu / \mathrm{GPP} \\
\left(\mathrm{CUE}_{\mathrm{a}} \times \mathrm{CUE}_{\mathrm{h}}\right) /\left(1-\mathrm{CUE}_{\mathrm{e}}\right)=\mu / \mathrm{GPP}\end{array}$ & $\begin{array}{l}\text { Ecosystem carbon budget } \\
\text { forecast }\end{array}$ & Sinsabaugh et al., 2017 \\
\hline
\end{tabular}

Note: The calculation and interpretation of the models can be seen in the corresponding references. 


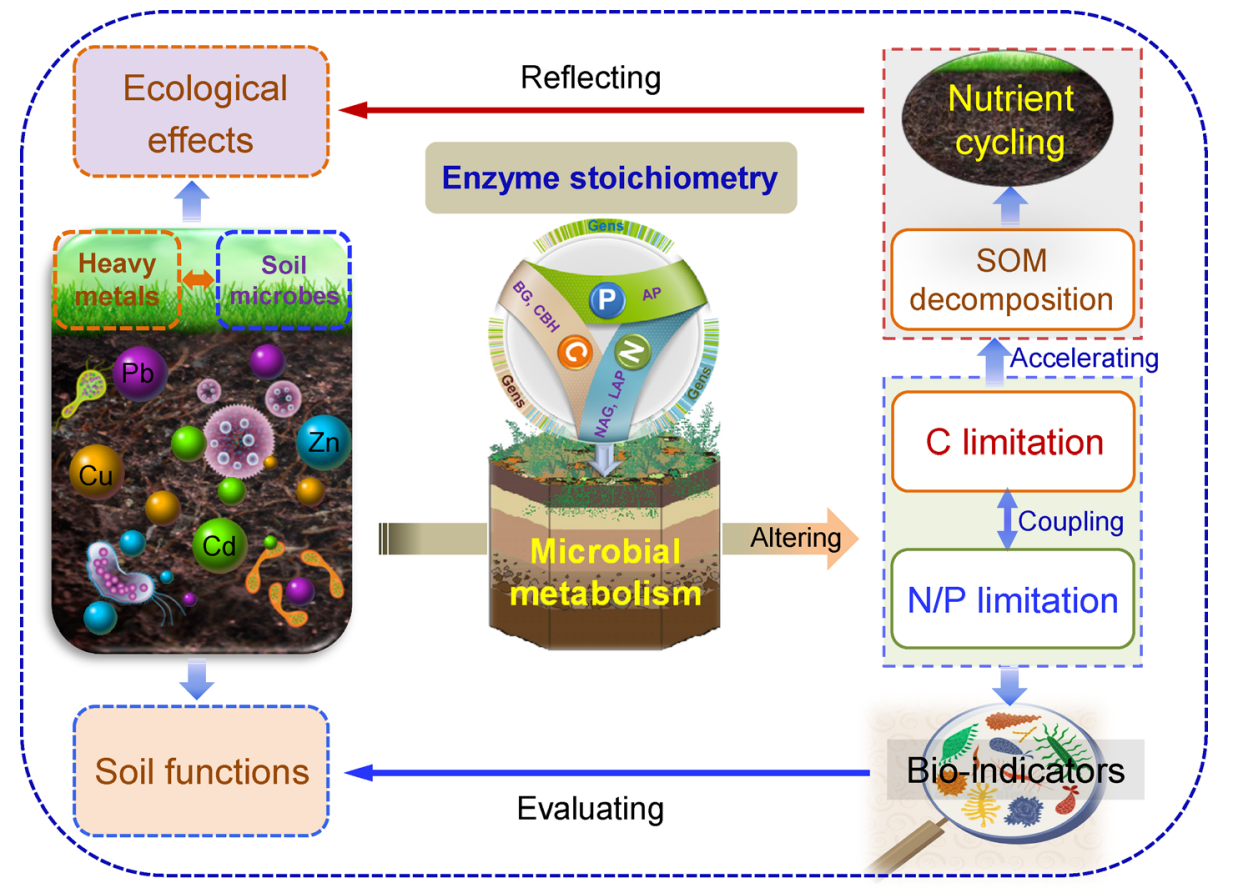

Fig. 1 The potential utility of ecoenzymatic stoichiometry as a new methodology for evaluating heavy metal soil contamination.

metals. As a result, more experimental evidence are needed to further support and verify the reliability and practicability of the ecoenzymatic stoichiometry methodology in evaluating soil heavy metal pollution.

\section{Conclusions}

This review unquestionably showed and commented on the utility of enzymes as tools for evaluating heavy metal pollution in soils. We also highlight that the advent of ecoenzymatic stoichiometry methodology offers a new avenue for evaluating heavy pollution in soils, potentially overcoming the limitations of classical enzymatic methods. More importantly, results from ecoenzymatic stoichiometry indicated that the methods provided new insight into the development of a promising indicator by which to monitor and assess heavy metal contamination and increase our understanding of the effects of heavy metal pollution in soil ecosystems. Several research directions will contribute to enlarge more and more the potentialities of soil enzymes and their exploitation for environmental purposes. First, advanced molecular biology techniques can help us identify and understand the physiologic responses at the molecular and genetic levels of microorganisms under heavy metal stress. While research in soil proteomic, metabolomic and transcriptomic studies is probably the most crucial challenge that soil enzymologists have faced. Secondly, in situ zymography techniques can further improve the determination accuracy of enzyme activities, thus improving the reliability of the enzyme-based methods. In addition, the optimization of relevant model parameters could eventually improve our assessment of the ecological effects of heavy metal pollution.

\section{Acknowledgments}

This study was financially supported by the National Natural Science Foundation of China (41977031) and the Science Foundation for Distinguished Youth of Shaanxi Province (2020JC-31).

\section{Electronic supplementary material}

Supplementary information provides additional tables and figures that show the extracellular enzymes commonly used in ecoenzymatic stoichiometry models and schematic example of the calculation of the RSSI-b score from areas under enzyme activities curves over time. Supplementary material is available in the online version of this article at https://doi.org/10.1007/ s42832-021-0096-0 and is accessible for authorized users.

\section{References}

Adam, G., Duncan, H., 2001. Development of a sensitive and rapid method for the measurement of total microbial activity using fluorescein diacetate (FDA) in a range of soils. Soil Biology \& Biochemistry 33, 943-951.

Ali, A., Guo, D., Zhang, Y., Sun, X., Jiang, S., Guo, Z., Huang, H., Liang, W., Li, R., Zhang, Z., 2017. Using bamboo biochar with compost for the stabilization and phytotoxicity reduction of heavy 
metals in mine-contaminated soils of China. Scientific Reports 7, 2690.

Bahram, M., Hildebrand, F., Forslund, S.K., Anderson, J.L., Soudzilovskaia, N.A., Bodegom, P.M., Bengtsson-Palme, J., Anslan, S., Coelho, L.P., Harend, H., Huerta-Cepas, J., Medema, M.H., Maltz, M.R., Mundra, S., Olsson, P.A., Pent, M., Põlme, S., Sunagawa, S., Ryberg, M., Tedersoo, L., Bork, P., 2018. Structure and function of the global topsoil microbiome. Nature 560, 233-237.

Bastida, F., Zsolnay, A., Hernández, T., García, C., 2008. Past, present and future of soil quality indices: a biological perspective. Geoderma 147, 159-171.

Bhuiyan, M.A.H., Parvez, L., Islam, M.A., Dampare, S.B., Suzuki, S., 2010. Heavy metal pollution of coal mine-affected agricultural soils in the northern part of bangladesh. Journal of Hazardous Materials 173, 384-392.

Burns, R.G., DeForest, J.L., Marxsen, J., Sinsabaugh, R.L., Stromberger, M.E., Wallenstein, M.D., Weintraub, M.N., Zoppini, A., 2013. Soil enzymes in a changing environment: Current knowledge and future directions. Soil Biology \& Biochemistry 58, 216234.

Cui, Y.X., Bing, H.J., Fang, L.C., Jiang, M., Shen, G.T., Yu, J.L., Wang, X., Zhu, H., Wu, Y.H., Zhang, X.C., 2019b. Extracellular enzyme stoichiometry reveals the carbon and phosphorus limitations of microbial metabolisms in the rhizosphere and bulk soils in alpine ecosystems. Plant and Soil 458, 7-20.

Cui, Y.X., Fang, L.C., Guo, X.B., Han, F., Ju, W.L., Ye, L.P., Wang, X., Tan, W.F., Zhang, X.C., 2019a. Natural grassland as the optimal pattern of vegetation restoration in arid and semi-arid regions: Evidence from nutrient limitation of soil microbes. Science of the Total Environment 648, 388-397.

Cui, Y.X., Fang, L.C., Guo, X.B., Wang, X., Zhang, Y.J., Li, P.F., Zhang, X.C., 2018. Ecoenzymatic stoichiometry and microbial nutrient limitation in rhizosphere soil in the arid area of the northern Loess Plateau, China. Soil Biology \& Biochemistry 116, 11-21.

Dagnino, A., Sforzini, S., Dondero, F., Fenoglio, S., Bona, E., Jensen, J., Viarengo, A., 2008. A weight-of-evidence approach for the integration of environmental "triad" data to assess ecological risk and biological vulnerability. Integrated Environmental Assessment and Management 4, 314-326.

Duan, C.J., Fang, L.C., Yang, C.L., Chen, W.B., Cui, Y.X., Li, S.Q., 2018. Reveal the response of enzyme activities to heavy metals through in situ zymography. Ecotoxicology and Environmental Safety 156, 106-115.

Epelde, L., Becerril, J.M., Hernández-Allica, J., Oihana, B., Garbisu, C., 2008. Functional diversity as indicator of the recovery of soil health derived from Thlaspi caerulescens growth and metal phytoextraction. Applied Soil Ecology 39, 299-310.

Facchinelli, A., Sacchi, E., Mallen, L., 2001. Multivariate statistical and GIS-based approach to identify heavy metal sources in soils. Environmental Pollution 114, 313-324.

Fang, L.C., Liu, Y.Q., Tian, H.X., Chen, H.S., Wang, Y.Q., Huang, M., 2017. Proper land use for heavy metal-polluted soil based on enzyme activity analysis around a $\mathrm{Pb}-\mathrm{Zn}$ mine in Feng County, China. Environ. Sci. Pollut. R. 24, 1-13.

Garnier, E., Cortez, J., Billès, G., Navas, M.L., Roumet, C., Debussche, M., Laurent, G., Blanchard, A., Aubry, D., Bellmann,
A., Neill, C., Toussaint, J.P., 2004. Plant functional markers capture ecosystem properties during secondary succession. Ecology 85 , 2630-2637.

German, D.P., Weintraub, M.N., Grandy, A.S., Lauber, C.L., Rinkes, Z. L., Allison, S.D., 2011. Optimization of hydrolytic and oxidative enzyme methods for ecosystem studies. Soil Biology \& Biochemistry $43,1387-1397$.

Gianfreda, L., Rao, M.A., Piotrowska, A., Palumbo, G., Colombo, C., 2005. Soil enzyme activities as affected by anthropogenic alterations: intensive agricultural practices and organic pollution. Science of the Total Environment 341, 265-279.

Griffiths, B.S., Bonkowski, M., Roy, J., Ritz, K., 2001. Functional stability, substrate utilisation and biological indicators of soils following environmental impacts. Applied Soil Ecology 16, 49-61.

Griffiths, B.S., Philippot, L., 2013. Insights into the resistance and resilience of the soil microbial community. FEMS Microbiology Reviews 37, 112-129.

Hagmann, D.F., Goodey, N.M., Mathieu, C., Evans, J., Aronson, M.F. J., Gallagher, F., Krumins, J.A., 2015. Effect of metal contamination on microbial enzymatic activity in soil. Soil Biology \& Biochemistry 91, 291-297.

Hinojosa, M.B., García-Ruíz, R., Viñegla, B., Carreira, J.A., 2004. Microbiological rates and enzyme activities as indicators of functionality in soils affected by the Aznalcollar toxic spill. Soil Biology \& Biochemistry 36, 1637-1644.

Hu, X.F., Jiang, Y., Shu, Y., Hu, X., Liu, L., Luo, F., 2014. Effects of mining wastewater discharges on heavy metal pollution and soil enzyme activity of the paddy fields. Journal of Geochemical Exploration 147, 139-150.

Jiang, R., Wang, M., Chen, W., Li, X., Baveye, P.C., 2019. Ecological risk of combined pollution on soil ecosystem functions: insight from the functional sensitivity and stability. Environ. Pollut. 255, 113184.

Ju, W.L., Liu, L.Q., Fang, L.C., Cui, Y.X., Duan, C.J., Wu, H., 2019. Impact of co-inoculation with plant-growth-promoting rhizobacteria and rhizobium on the biochemical responses of alfalfa-soil system in copper contaminated soil. Ecotoxicology and Environmental Safety 167, 218-226.

Kandeler, E., Tscherko, D., Bruce, K.D., Stemmer, M., Amelung, W., 2000. Structure and function of the soil microbial community in microhabitats of a heavy metal polluted soil. Biology and Fertility of Soils 32, 390-400.

Lessard, I., Sauvé, S., Deschênes, L., 2014. Toxicity response of a new enzyme-based functional diversity methodology for $\mathrm{Zn}$ contaminated field-collected soils. Soil Biology \& Biochemistry 71, 87-94.

Li, Z., Ma, Z., Kuijp, T.J.V.D., Yuan, Z., Huang, L., 2014. A review of soil heavy metal pollution from mines in china: pollution and health risk assessment. Science of the Total Environment 468, 843-853.

Liang, Q., Gao, R., Xi, B., Zhang, Y., Zhang, H., 2014. Long-term effects of irrigation using water from the river receiving treated industrial wastewater on soil organic carbon fractions and enzyme activities. Agricultural Water Management 135, 100-108.

Long, C., Zhou, D.M., Wang, Q.Y., Wu, D.Y., 2009. Effects of electrokinetic treatment of a heavy metal contaminated soil on soil enzyme activities. Journal of Hazardous Materials 172, 16021607. 
Lyubun, Y.V., Pleshakova, E.V., Mkandawire, M., Turkovskaya, O.V. 2013. Diverse effects of arsenic on selected enzyme activities in soil-plant-microbe interactions. Journal of Hazardous Materials 262, 685-690.

Marinari, S., Carbone, S., Vittori Antisari, L., Grego, S., Vianello, G., 2012. Microbial activity and functional diversity in Psamment soils in a forested coastal duneswale system. Geoderma 173 , $249-257$.

Moorhead, D.L., Sinsabaugh, R.L., Hill, B.H., Weintraub, M.N., 2016. Vector analysis of ecoenzyme activities reveal constraints on coupled C, N and P dynamics. Soil Biology \& Biochemistry 93, 1-7.

Mora, A.P., Ortega-Calvo, J.J., Cabrera, F., Madejón, E., 2005. Changes in enzyme activities and microbial biomass after "in situ" remediation of a heavy metal-contaminated soil. Applied Soil Ecology 28, 125-137.

Nannipieri, P., Kandeler, E., Ruggiero, P., 2002. Enzyme activities and microbiological and biochemical processes in soil. In: Burns, R.G., Dick, R.P. (Eds.), Enzymes in the Environment: Activity, Ecology and Applications. Marcel Dekker, New York, pp. 1-33.

Pignataro, A., Moscatelli, M.C., Mocali, S., Grego, S., Benedetti, A., 2012. Assessment of soil microbial functional diversity in a coppiced forest system. Applied Soil Ecology 62, 115-123.

Puglisi, E., Del Re, A.A.M., Rao, M.A., Gianfreda, L., 2006. Development and validation of numerical indexes integrating enzyme activities of soils. Soil Biology \& Biochemistry 38, 1673 1681.

Rao, M.A., Scelza, R., Acevedo, F., Diez, M.C., Gianfreda, L., 2014. Enzymes as useful tools for environmental purposes. Chemosphere 107, 145-162.

Schloter, M., Nannipieri, P., Sørensen, S.J., Elsas, J.D.V., 2017. Microbial indicators for soil quality. Biology and Fertility of Soils 54 , 1-10.

Shen, F., Liao, R., Ali, A., Mahar, A., Guo, D., Li, R., Sun, X., Awasthi, M.K., Wang, Q., Zhang, Z., 2017. Spatial distribution and risk assessment of heavy metals in soil near a $\mathrm{Pb} / \mathrm{Zn}$ smelter in Feng county, China. Ecotoxicology and Environmental Safety 139, 254 262.

Sinsabaugh, R.L., Follstad Shah, J.J., 2012. Ecoenzymatic stoichiometry and ecological theory. Annual Review of Ecology, Evolution, and Systematics 43, 313-343.

Sinsabaugh, R.L., Hill, B.H., Shah, J.J.F., 2009. Ecoenzymatic stoichiometry of microbial organic nutrient acquisition in soil and sediment. Nature 462, 795-798

Sinsabaugh, R.L., Lauber, C.L., Weintraub, M.N., Ahmed, B., Allison, S.D., Crenshaw, C., Contosta, A.R., Cusack, D., Frey, S., Gallo, M. E., Gartner, T.B., Hobbie, S.E., Holland, K., Keeler, B.L., Powers, J. S., Stursova, M., Takacs-Vesbach, C., Waldrop, M.P., Wallenstein, M.D., Zak, D.R., Zeglin, L.H., 2008. Stoichiometry of soil enzyme activity at global scale. Ecology Letters 11, 1252-1264.

Sinsabaugh, R.L., Moorhead, D.L., Xu, X., Litvak, M.E., 2017. Plant, microbial and ecosystem carbon use efficiencies interact to stabilize microbial growth as a fraction of gross primary production. New Phytologist 214, 1518-1526.
Tapia-Torres, Y., Elser, J.J., Souza, V., García-Oliva, F., 2015. Ecoenzymatic stoichiometry at the extremes: how microbes cope in an ultra-oligotrophic desert soil. Soil Biology \& Biochemistry 87 , 34-42.

Trevors, J.T., 1984. Dehydrogenase in soil: a comparison between the INT and TTC assay. Soil Biology \& Biochemistry 16, 673-674.

US Environmental Protection Agency, 2016. Generic Ecological Assessment Endpoints (GEAEs) for Ecological Risk Assessment: Second Edition with Generic Ecosystem Services Endpoints Added. USEPA, Risk Assessment Forum, Washington DC.

Violante, A., Cozzolino, V., Perelomov, L., Caporale, A.G., Pigna, M., 2010. Mobility and bioavailability of heavy metals and metalloids in soil environments. Journal of Soil Science and Plant Nutrition 10 , 268-292.

Wahsha, M., Nadimi-Goki, M., Fornasier, F., Al-Jawasreh, R., Hussein, E.I., Bini, C., 2017. Microbial enzymes as an early warning management tool for monitoring mining site soils. Catena $148,40-45$.

Wang, M., Faber, J.H., Chen, W., 2017b. Application of stress index in evaluating toxicological response of soil microbial community to contaminants in soils. Ecological Indicators 75, 118-125.

Wang, X., Cui, Y., Zhang, X., Ju, W., Duan, C., Wang, Y., Fang, L., 2020. A novel extracellular enzyme stoichiometry method to evaluate soil heavy metal contamination: evidence derived from microbial metabolic limitation. Science of the Total Environment 738, 139709.

Wang, Y., Wang, R., Fan, L., Chen, T., Bai, Y., Yu, Q., Liu, Y., 2017a. Assessment of multiple exposure to chemical elements and health risks among residents near Huodehong lead-zinc mining area in Yunnan, Southwest China. Chemosphere 174, 613-627.

Wang, Z., Tian, H., Tan, X., Wang, F., Jia, H., Megharaj, M., He, W., 2019. Long-term As contamination alters soil enzyme functional stability in response to additional heat disturbance. Chemosphere 229, 471-480.

Wood, J.L., Tang, C., Franks, A.E., 2016. Microbial associated plant growth and heavy metal accumulation to improve phytoextraction of contaminated soils. Soil Biology \& Biochemistry 103, 131-137.

Xian, Y., Wang, M., Chen, W., 2015. Quantitative assessment on soil enzyme activities of heavy metal contaminated soils with various soil properties. Chemosphere 139, 604-608.

Xu, Y., Seshadri, B., Sarkar, B., Wang, H., Rumpel, C., Sparks, D., Farrell, M., Hall, T., Yang, X., Bolan, N., 2018. Biochar modulates heavy metal toxicity and improves microbial carbon use efficiency in soil. Science of the Total Environment 621, 148-159.

Yang, J., Yang, F., Yang, Y., Xing, G., Deng, C., Shen, Y., Luo, L., Li, B., Yuan, H., 2016. A proposal of "core enzyme" bioindicator in long-term $\mathrm{Pb}-\mathrm{Zn}$ ore pollution areas based on topsoil property analysis. Environmental Pollution. 213, 760-769.

Zota, A.R., Willis, R., Jim, R., Norris, G.A., Shine, J.P., Duvall, R.M., Schaider, L.A., Spengler, J.D., 2009. Impact of mine waste on airborne respirable particulates in Northeastern Oklahoma, United States. Journal of the Air \& Waste Management Association 59, $1347-1357$ 